\title{
NEW NORMAL LEARNING SYSTEM AND TEACHERS EFFICACY OF RIZAL MEMORIAL COLLEGES, INC.
}

\author{
Angelica Kean Bantasan ${ }^{1}$, Ma. Melanie N. Edig ${ }^{2}$, Ronald S. Decano ${ }^{3}$ \\ ${ }^{1}$ Graduate Student, Doctor of Philosophy in Educational Management, Davao del Norte State College \\ ${ }^{2}$ Faculty, Institute of Advanced Studies, Davao del Norte State College \\ ${ }^{3}$ Dean, Institute of Advanced Studies, Davao del Norte State College
}

Article DOI: https://doi.org/10.36713/epra9376 DOI No: 10.36713/epra9376

\begin{abstract}
The researcher wanted to investigate if teachers' efficacy is major factors of learners' academic success and to all school stakeholders. The respondents of this study were composed of 75 IBED teachers from Private School of Davao City. The main purpose of this study is to determine the significant relationship between the new normal learning system and teacher's efficacy. Based on the research questions, the findings disclosed the extent of the new normal learning system of IBED teachers from Private School of Davao City in terms of: blended learning modality; asynchronous learning modality, and distance learning modality. On the other hand, for other concerns of this study, what is the extent of teacher's efficacy in terms of social persuasions; verbal encouragement; and vicarious experiences, the results implied that the new normal learning system rapid move to a new learning model of education may emerge, with significant benefits, believed that the integration of in any new normal learning system in education help further acceleration and integral component of teacher's efficacy, further discussed the mean rating with a descriptive equivalent of extensive, which indicates that extent of teacher's efficacy is constantly evident, Hence, the decision is to reject the null hypothesis. This signified the domain of the new normal learning system significantly influences teacher efficacy. Furthermore, the results provide administration, school principals, and teachers as reliable bases in improving their supervisory services amidst the new normal learning system.
\end{abstract}

KEYWORDS: New normal learning system, and teacher's efficacy

\section{INTRODUCTION}

Educating people is more than simply passing on information; it's a critical part of fostering their growth as individuals and as a society as a whole. When it comes to preparing the next generation of society's leaders, it is essential. Both instructors and students in the new normal system are more heavily reliant on technology in order to study in the new system.

This context explores how the educational system improved and changed its way or solutions through with the new learning system and how it affects the self-efficacy of every teacher and student in a school. Within the new normal, the situation presents a unique challenge to every educational leader for how the process will be thorough (Custodio, A et al., 2020).

Hence, to sustain the delivery of quality instruction to every school, it presents opportunities for responding to issues, problems, and trends that will arise in the future due to the COVID-19 pandemic. Researchers have a keen interest in the current and future trends in the new normal learning system towards quality education. 
According to Uy, A. R (2020), what is worth studying after returning to normality, are the implications that have arisen for the day after, that is, what adjustments need to be made, the extent of the situation, and to define the basic dimensions of education and to learn in formal education systems and organizations amid educational disruptions. What has become 'normal'? The lockdowns, quarantines, masks, washing hands, taking vitamins and nutrient-rich food to nurture health, covering a coughing mouth and sneezing nose, physical distancing, and the omnipresent support technology are a "must" to continue for a lifetime.

Globally, the coronavirus pandemic has spawned a consequent concern of our educational institutions to carry on their respective missions by providing online learning sessions. With this format, there are among our students who feel inadequate to attend to their assigned readings in their subjects. They have been used to their lecturers to explain to them in more informal ways the website material. While there are apps to remedy these virtual class sessions, such as virtual interchange through chats or zoom or Google classroom, these apps though available, are not always readily accessible because of the unevenness of internet accessibility (Custodio, A et al., 2020).

People and the media have brought up this issue time and time again. However, we can help them in another way as well, which is by encouraging teachers to believe in their own self-efficacy Mulenga \&Marban (2020). COVID-19 has been a worldwide pandemic, and most nations have closed their schools for a pandemic month to control the disease and limit the number of infections (UNESCO, 2020).

More than 1.2 billion students throughout the globe, including more than 28 million in the Philippines, have been impacted by this shutdown (UNESCO, 2020). Many nations have responded to the crisis by instituting lockdowns and quarantines, which have prompted students and instructors to work and study from home. Teachers and students at higher education institutions, in particular, faced unique obstacles and hazards while implementing online learning (Custodio, A. et al., 2020).

In the Philippine context, concerning the new normal system, most of the developed self-efficacy scale focuses on one source of self-efficacy and is constructed as a subscale. Given the limited published issues about the new normal learning modalities for Filipino and the non-existence of published and established research studies in the Philippine context, this is sought to find and explore how teachers' efficacy scale is more holistic than those previously published.

In addition, the Philippines' Department of Education (DepEd) began preparing for a new normal in education as the nation battled the COVID-19 epidemic. To provide education to students, DepEd undertook a countrywide consultation with stakeholders and education professionals. DepEd will offer Self-Learning Modules (SLMs) with alternate learning delivery modalities for diverse kinds of learners throughout the Philippines, including modular, television-based, radio-based instruction, blended, and online, in preparation for School Year 2020-2021. SLMs are produced and sent to schools in remote locations, including coastal regions and remote provinces, and communities that do not have access to power or the internet. According to the department's announcement, SLMs may now be accessible online or offline for houses equipped with modern technology.

On the other hand, In the Philippines, there are 10,794 cases as of May 11, 2020, and it is still increasing (DOH, 2020), with more than four million cases worldwide (Worldometer, 2020). In the new learning system, teachers provide learning materials; aim proved their higher self-efficacy in their performance and more use of their self-organized tactics than those who were given the performance goals.

In the local context, the rapid growth of the internet brings up the question of whether the gender, age, and computer use issues reported earlier would be present concerning the Internet. Based on workforce readiness and computer usage, this study looked into the case of Cagayan State University (CSU).

According to Aparri (2018) and a more effective means of eliminating or reducing the anxiety of using computers. This benchmark survey will somehow benefit the school and the administration, and teachers by providing equal opportunities to use computers and the internet and in preparing the teachers with the technical skills afforded to them (Aparri 2018).

In addition to that, the new learning system and teacher self-efficacy is the confidence of one's competence to use the computer, and those with no or little confidence in their ability to use computers might do more poorly on computer-related tasks. MaimunahMohd Shah (2017) exclaimed that teachers with a high attitude towards computers experienced high computer knowledge but low computer anxiety. Computer self-efficacy was found to be associated with attitudes toward computer technologies.

I believe that similar studies had been conducted about the new normal learning system and teachers efficacy. This study differs from other related studies because given the breadth of the academic involvement construct, there is no consistent or single definition of the new normal learning system and teacher's efficacy. Furthermore, 
different terms are used to refer to what indicators best factors considered of the new normal learning system and teachers efficacy.

This study also differs from its locality because most are from other localities and countries. Furthermore, this study is relative to society's current situation because new normal learning system and teacher's efficacy provide children support to practice and motivate to develop what they have learned in school.

Effective administrators develop a sense of school community and its accompanying traits to transform this sort of atmosphere and begin to counteract isolation, closed doors, negativity, defeatism, and teacher opposition. All members of the school community should be respected and treated with dignity and courtesy, as well as being solution-oriented, without assigning blame, and professional. To have a better understanding of the new normal learning method and the effectiveness of instructors in particular at the IBED department from a private school in Davao City, this research should be undertaken promptly.

This study is timely and needs to be addressed to provide proper actions and recommendations to all school stakeholders. Thus, there are a lot of challenges in implementing new normal learning modality related to teacher efficacy.

\section{Research Design}

\section{METHODOLOGY}

The research design of this study utilized a quantitative, non-experimental descriptive-correlational method because this study determines the relationship between the new normal learning system and teacher's efficacy of Rizal Memorial Colleges, Inc. Davao city. To illustrate this research design, Creswell (2015) stated that, it is a design that is used by investigators to describe and measure the degree of relationship between two or more variables or a set of scores, it is effective for this study because of the two variables that are present, the independent variable "new normal learning system" and the dependent variable "teacher efficacy" and that the researchers may meet their perspective on both variables. In this research design, the researcher will determine the relationship between the two variables, and it is the most accurate design that can be used according to the topic.

\section{Research Respondents}

The respondents of this study were composed of 80 teachers from Rizal Memorial Colleges, Inc. Davao City. The inclusion criteria for research respondents were the IBED teacher having more than 3 years in service from grade level 4-12, respondents were the one that who were gave the researchers needed information or data that answered the study through a structured survey questionnaire. The research respondents honestly filled up the information needed in the structured survey questionnaire distributed accordingly via a Google form. The researcher used a random sampling method to use a proportional number of respondents from Rizal Memorial Colleges, Inc. Davao City.

Random sampling was a subset of individuals chosen from a large set. Each individual was chosen randomly and entirely by chance, such that each individual has the probability of being chosen at any stage during the sampling process. The results would be valid because of the specified respondents. The researcher took the survey seriously to gather results to match and be accepted by the statistician.

\section{Research Instrument}

A self-made instrument was prepared with the guidance of the thesis adviser and evaluators and was used to gather the needed data to realize the work. The questionnaire has 3 aspects (indicators) for the independent variable, focused on blended learning modality, asynchronous learning modality, and distance learning modality, while the dependent variable considered the 3 indicators namely: social persuasion, verbal encouragement, and vicarious experience. Each indicator has five (5) questions that can be answered through the given legend. Simple instructions can be seen in the questionnaires.

The research questionnaires were purely research made and was not adopted. The concept of the questionnaire was submitted and was evaluated by a grammarian. The suggestions and evaluation tools were given to help the researchers improve and make the research instrument in its best form. The outcome of the evaluation and validation and the research instrument's draft were submitted to the research adviser for finalization. Unclear statements were removed; weak statements were strengthened and polished. 
After the finalization by the research adviser, the research instrument is now prepared. After the evaluation and approval of the questionnaires, Google form is used as a tool for the online survey in gathering data and information from the respondents. The researchers administered the questionnaires via Google form set up for the Pilot Testing to practice and abide the government ordinance supervised by the Inter-Agency task force (IATF) that always keeps social distancing and prevents gathering and mingling in leisure. Also, to adhere to the DepEd order that all teachers are needed to help by doing any activities to hamper the prevalent covid-19 virus or diminish.

\section{Data Gathering Procedure}

The necessary data underwent the following gathering procedure:

The researcher asked for an endorsement to conduct the study from the Dean of the Graduate School, Dr. Pablo F. Bosquit. A letter request attached with the Dean's endorsement was forwarded. A letter of permission was submitted to the school Principal to seek approval for the conduct of the survey before the research instrument was administered via Google form to adopt the new learning system of the new education policy. After getting permission, the survey was conducted. The researchers administered the research instrument personally via Google form conveniently. The researchers will undergo the following procedures in gathering data:

A letter of permission was submitted to the school Principal to seek approval for the conduct of the survey before the research instrument was administered via Google form to adapt the new learning system of the new education policy. After getting permission, the survey was conducted.

The researcher administered the research instrument personally via Google form at a convenient time. Retrieval of the questionnaire. After administering the instruments, the responses were retrieved and tallied, and then forwarded to the statistician for data treatment.

\section{Data Analysis}

The following statistical tools will be used to treat the data:

Mean. This will determine the extent of the new normal learning system and teacher's efficacy of Rizal Memorial Colleges, Inc. Davao City.

Pearson's Product Moment Coefficient of Correlation. This tool will determine the relationship between the new normal learning system and teacher's efficacy of Rizal Memorial Colleges, Inc. Davao City.

Regression. This tool will be used to determine the domain of the new normal learning system that significantly influences teachers' efficacy of Rizal Memorial Colleges, Inc. Davao City.

\section{RESULT AND DISCUSSION}

In the light of the findings drawn out by the researcher in this study the following Conclusions and recommendations are offered:

The new normal learning system got mean rating of 4.12 with the standard deviation of 0.412 and the teacher efficacy got the mean rating of 4.43 with the standard deviation of 0.443 . The Pearson-R correlation result showed 0.425 which means there is a moderate correlation at a significant level of .000 which means a significant relationship between the new normal learning system and teacher's efficacy. It explains that if the new normal learning system is positively demanding, teacher efficacy is much more motivated. Hence, the decision is to reject the null hypothesis.

The null hypothesis of the study stated that there is no significant relationship between the new normal learning system and the teacher efficacy, the result of the study implied the that there is a significant relationship between the new normal learning system and teacher efficacy. Hence, the decision is to reject the null hypothesis. However, as evidence from the literature review, many studies have been done on new normal learning system and teachers' efficacy in the international, national and local scenario.

This signifies the relation between the new normal learning system and teacher's efficacy to provide school principals and administration reliable bases in improving their supervisory services amidst new learning modalities. However, the literature reviewed said that on new normal learning system and teacher efficacy is needed convergent, new normal learning system domain significantly influences the teacher efficacy it shows that the value of the regression Analysis F ratio is 26.43, with a significant level of .000.

This simply means that the new normal learning system indicators and teacher efficacy significantly influence the indicators considered of this study. The decision is to reject the null hypothesis, which implied that there is a domain of new normal learning system that significantly influences teacher efficacy. The second indicator 
"asynchronous learning modality" with a descriptive equivalent of very extensive, indicates that the extent of the new normal learning system in terms of asynchronous learning modality is always evident.

The third indicator "distance learning modality" with a descriptive equivalent of very extensive indicates that the extent of the new normal learning system in terms of distance learning modality is always evident.

Therefore, internet usage may help the teacher's self-efficacy connected to the outcomes of learners which have big influence in their performance in teacher learning process including their interaction and pedagogy

\section{CONCLUSIONS AND RECOMMENDATIONS}

This study determined the relationship between the new normal learning system and teachers' efficacy of Rizal Memorial Colleges, Inc. Davao City. Extent of new normal learning system in terms of blended learning modality; asynchronous learning modality and distance learning modality and for the extent of teacher's efficacy Rizal Memorial Colleges, Inc. Davao City in terms of social persuasions; verbal encouragement; and vicarious experiences.

This study highlights also the significant relationship between new normal learning system and teachers' efficacy Rizal Memorial Colleges, Inc. Davao City and the domain of new normal learning system that significantly influences the teachers' efficacy Rizal Memorial Colleges, Inc. Davao City.

There is no doubt that the roles of teachers in today's world of education have enlarged considerably.. Therefore, this benchmark result somehow benefits the school as well as the administration and teachers by providing equal opportunities to know the new normal learning system and the teacher efficacy, and in preparing the teachers with the technical skills afforded to them. In addition to that, the new learning system and teacher efficacy is the confidence of one's competence and ability to embrace any new normal learning system of education. In this context, it explores how the educational system improved and changed its way or solutions through the new learning system and how it affects the self-efficacy of every teacher in the school.

Furthermore, self-efficacy can be influenced by behavioral outcomes such as goal progress and achievement and by environmental inputs such as feedback from teachers and social comparisons with peers. However, teachers interpret the new normal learning system should provide the most reliable influence on teacher efficacy because performances are tangible indicators of one's capabilities. New normal learning system viewed as successful should raise teacher self-efficacy.

Teachers' self-efficacy is one of the strongest predictors of teacher's towards students' academic performance. It is a belief that he or she can accomplish whatever that individual is doing, is the process from person to behavior to outcome.

The results of this study are to serve as a guide for the administrator, school principal, and teacher to understand and find solutions for this existing problem, how do teacher efficacy and the new learning system is related. The study mentioned is one of the common struggles that an individual encounters as the time today's education system changed. This study may help develop different pedagogies and enhance teachers' efficacy genuinely, a kind of style in teaching to embrace new learning modalities. This may also serve as the basis for improvement. The finding of the study may serve a significant role and would provide valuable information to the following entities:

The School Administrator will be informed on the status regarding the new normal learning system and teachers efficacy for them to open rooms for improvement, ideas into possible changes for the betterment of the school.

Principal. The results will provide school principals and administration with reliable bases for improving supervisory services.

Teachers. The findings of this study will help sharpen the system and activity plan of the public-school teachers in the capability to manage their classes adopting any applicable and suitable learning modalities. The findings will also make them aware and encourage them to exert effort and devote quality time in improving selfefficacy with guidance and assistance provided by their superiors.

Future researchers. This study may be a reference for future researchers if they have to venture this kind of research. 


\section{ACKNOWLEDGEMENT}

I, Angelica Kean A. Bantasan, would like to extend my heartfelt appreciation and gratitude to the following people who contributed immeasurably to the success of this piece of work. Dr. Ronald Decano, research adviser and the Dean of the Graduate School of Davao del Norte State College for his encouragement to finish this research. The examiners panel shares their constructive comments and suggestions that helped me improve this manuscript well. To Dr. Mark Van M. Buladaco, who was helping and finishing this paper for publication. In addition, I would also like to thank my parents and friends for being my inspiration and to their support. To my teachers respondents who contributed greatly to make this manuscript possible within a limited time frame. Finally, and most importantly, I would like to thank to our almighty God for the guidance and power 1 to achieve this great goal

\section{REFERENCES}

1. Aguinaldo, B. (2018). Implementing blended learning in an impoverished academicinstitution using abricolage approach model.International Journal of Information and Education Technology,

2. Allen, I. E., et al, (2019). Online report card: Tracking online education in the UnitedStates, 1-4.

3. Ally, M., Prieto-Blazquez, J. (2017). Special Section "Mobile Learning Applications inHigher Education". RUSC. Universitiesand Knowledge Society Journal 11(1):142.

4. Alfonso, G. J. (2018). UP Open University: Thoughts about openness in a digitizedworld [PowerPoint slides]. Presentation at the UPOU Roundtable Discussion, POU Oblation Hall, Los Banos, Laguna.

5. Anderson, T. (2018). Towards a theory of online learning. In T. Anderson (Ed.). The theory and practice of online learning (2nd ed.; pp. 45-74). Alberta, Canada: Athabasca University Press.

6. Anderson, T. (2019). Three generations of distance education pedagogy. International Review ofResearch in Open and Distributed Learning 12(3): 80-97.

7. Aparri, B., (2018). Computer Anxiety, Self - Efficacy and Attitudes towards Internet ofCagayan StateUniversity Students.

8. Aud, S., et al, (2019). The condition of education - 2010. Education, 4-29.

9. Bandura, A. (1994). "Self-efficacy," in Encyclopedia of Human Behavior, Vol. 14, ed. V. S. Ramachaundran (New York:Academic Press), 71-81.

10. Bandura, A. (1997). Self-efficacy: The exercise of control. New York: W. H. Freeman.

11. Brown, L. J., Malouff, J. M., and Schutte, N. S. (2018). Self-Efficacy Theory. Armidale, NSW: University of New England.

12. Bunglowala, A \&Bunglowala, A. (2019). Non-verbal communication: An integral part of teaching learning process. International Journal of Research in Advent. Technology Special Issue 1st International Conference on Advent Trends in Engineering. Science and Technology 8 Maret "ICATEST 2015",371-375.

13. Custodio, A. (2020). Blended learning is the new normal in Philippine education. The Manila Times.

14. Dziuban, C., Picciano, A. G., Graham, C. R., \&Moskal, P. D. (2016). Conducting research in online and blended learningenvironments: New pedagogical frontiers. New York: Routledge, Taylor \& Francis Group.

15. Elearnspace. (2018). Blended. http://www.elearnspace.org/doing/blended.htm.

16. Estacio, RR and Raga Jr RC (2017). Analyzing student online learning behavior in blended course using Moodle Asian Assoc. of Open Universities J. vol 12 no 1pp 52-68.

17. Graham, C. R. (2018). Emerging practice and research in blended learning. In M. G. Moore (Ed.), Handbook of distance education, (3rd ed., pp. 333-350). NewYork: Routledge

18. Hilliard, A. T. (2018). Global Blended Learning Practices for Teaching and Learning, Leadership and Professional Development.Journal of International EducationResearch, v11 n3 p179-188 2015.

19. Hodges, C. B. (2018). Self-efficacy in the context of online learning environments: A review of the literature and directions forresearch. Performance ImprovementQuarterly, 20(3-4): 7-25.

20. Hughes, G. (2017). Using blended learning to increase learner support and improve retentions Teaching in Higher Educ. vol 12 no 3 pp 349-63.

21. Hughes and Raman (2020).Cheung, K.S., Lam, J., Im, T., Szeto, R.: Some Principles for Good Practices of eLearning in Continuum.

22. Joo, Y. J., Lim, K. Y., \& Kim, J. (2018). Locus of control, self-efficacy, and task value as predictors of learning outcome in an online university context. Computers \&Education, 62, 149-158.

23. Kim, Y. H. (2019). U.S. Patent No. 7,594,132. Washington, DC: U.S. Patent and Trademark Office.

24. MaimunahMohd Shah (2017) J.: A Review of Functional Features of e-Learning Platform in the Continuing Education Context.

25. International Journal of Continuing Education and Lifelong Learn.

26. Mateo, (2020). Education in the United States, Needham. Sloan Consortium.

27. Mindflash, (2020). Synchronous e-learning involves online studies through chat and videoconferencing. 
28. Mulenga \&Marban, (2020). Blended Learning Systems: Definition, Current Trends, and Future Directions. In: Bonk, C.J.,

29. Graham, C.R. (eds.) Handbook of Blended Learning: Global Perspectives, Local Designs.

30. Org, (2020). Synchronous Learning Vs. Asynchronous Learning in Online Education.

31. Tumapon, (2020). Learning Education Institutions. In: Proceedings of the International Conference on ICT in Teaching andLearning. Open Uni

32. Uy, A. R. (2020). "Blended Learning" In Virus-Hit Philippines. The ASEAN posts reserved 2020.

33. Wagler, R. (2011). The Impact of Vicarious Experiences and Field Experience Classroom Characteristics on PreserviceElementary Science Teaching Efficacy

34. Zenon, E M. (2006). A Study of the Correlation Between Internet Access and Academic Achievement, and Internet Use and Academic Achievement, in Middle School Students. 